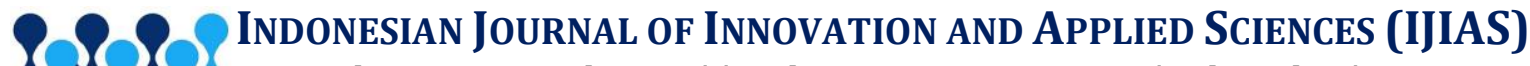 \\ Journal Homepage: https://ojs.literacyinstitute.org/index.php/ijias \\ ISSN: 2775-4162 (Online) \\ Research Article
}

\begin{tabular}{l|l|l|l|l}
\hline Volume 2 & Issue 1 & February (2022) & DOI: 10.47540/ijias.v2i1.322 & Page: $1-11$
\end{tabular}

\section{Mycological Indoor Air Quality Assessment of Ultra-Modern Market Grains' Grinding Mills in Dutse, Northwest Nigeria}

\author{
Adeleye Adeniyi Olarewaju ${ }^{1}$, Abdullahi Ibrahim ${ }^{1}$, Bate Garba Barde ${ }^{1}$, Amoo Florence Kemi ${ }^{2}$, \\ Asaju Catherine Iyabo ${ }^{1}$, Yerima Mohammed Bello ${ }^{2}$ \\ ${ }^{1}$ Department of Environmental Sciences, Federal University Dutse, Nigeria \\ ${ }^{2}$ Department of Microbiology and Biotechnology, Federal University Dutse, Nigeria \\ Corresponding Author: Adeleye Adeniyi Olarewaju; Email: adeniyi.adeleye@fud.edu.ng
}

\begin{tabular}{|c|c|}
\hline A R T I C LE I N F O & A B S T R A C T \\
\hline $\begin{array}{l}\text { Keywords: Colony Forming Unit, } \\
\text { Grains, Grinding Mills, Indoor Air } \\
\text { Quality, Mycology. }\end{array}$ & $\begin{array}{l}\text { This research aimed to assess the mycological indoor air quality of the grains' } \\
\text { grinding mills situated in the Dutse ultra-modern market. A simple random } \\
\text { sampling method was employed to select nine (9) shops where grains are milled. }\end{array}$ \\
\hline : 09 August 2021 & (SDA) plates was adopted for fungal isolation in the morning, afternoon and \\
\hline : 01 February 2022 & evening. Fungal isolates were subsequently identified using standardized methods. \\
\hline Accepted : 04 February 2022 & $\begin{array}{l}\text { Results obtained indicate that depending on the sampling period and operation } \\
\text { status of the grinding mills, all the sampling points examined were heavily } \\
\text { contaminated with total mean fungal load in the morning }\left(4084 \mathrm{CFU} / \mathrm{m}^{3}\right) \text {, evening } \\
\left(3867 \mathrm{CFU} / \mathrm{m}^{3}\right) \text {, and afternoon }\left(3818 \mathrm{CFU} / \mathrm{m}^{3}\right) \text {. However, the mean fungal load } \\
\text { obtained in the morning from shop } \mathrm{C}\left(6426 \mathrm{CFU} / \mathrm{m}^{3}\right) \text { was significantly different } \\
\text { from other shops ( } \mathrm{p}<0.05) \text { while the mean fungal loads obtained across all the } \\
\text { shops in the afternoon and evening were not significantly different from each other } \\
(\mathrm{p}>0.005) \text {. Mucor plambeaus }(22.22 \%) \text {, Aspergillus flavus }(16.67 \%) \text {, Aspergillus } \\
\text { niger }(20.37 \%) \text {, Fusarium spp. ( } 22.22 \%) \text { and Penicillium spp. (18.52\%) were } \\
\text { isolated across the grinding mills. Results obtained indicate that depending on the } \\
\text { time of the day and operation status of the grinding mills, the studied indoor } \\
\text { environment allowed fungal aerosols to build up which could serve as a potential } \\
\text { reservoir of fungal infections. It is therefore recommended that safety measures } \\
\text { should be adopted with a view to reducing fungal pollution at the grains' grinding } \\
\text { mills. }\end{array}$ \\
\hline
\end{tabular}

\section{INTRODUCTION}

Indoor air quality (IAQ) signifies the parameters of air present in an enclosed building. Pollutants that are found in a typical indoor environment can vary based on the prevailing anthropogenic interference, biological and chemical resources available at any point in time. Air is composed of gas that contains a mixture of mostly Nitrogen and Oxygen. The need for air in terms of the survival of humans, animals, and plants cannot be substituted. The quality of the air needed for breathing plays a huge role in defining the health status of humans and animals (Adeleye et al., 2018). According to Nejadkoorki (2015), microbial toxins, bacteria, fungi, yeasts, volatile organic compounds, viruses, protozoa, insect allergens, pet and insect allergens are some of the elements that are found in the air. Depending on the microorganisms involved, exposure to bio-aerosols can lead to the development of asthma, contact dermatitis, chronic bronchitis, rhinitis, sinusitis, hypersensitive pneumonitis, organic dust toxic syndrome, and aspergillosis in immunosuppressed individuals (Bünger et al., 2000; Douwes et al., 2003; Viegas et al., 2015). Evidence that people working in grains' grinding mills developing respiratory ailments have been reported by Dacarro et al. (2005). 
Fungi and bacteria play a huge role in inducing the quality of the indoor air environment (Abed, 2014). This author submitted further that dankness and insufficient ventilation aid the presence of several biological agents in an indoor environment. According to World Health Organization (WHO), people that reside in moldy buildings are at great risk of developing respiratory ailments and aggravation of asthma (McMahon et al., 2012). Walking, talking, sneezing, and coughing are some of the human activities that can freely breed airborne biological particulate matter in an indoor environment (Adeleye et al., 2018). Consequently, the need to conduct air quality monitoring to extricate between the causative agents that produce unfriendly health effects is inevitable (Madukasi et al., 2010).

Environmental factors like temperature and relative humidity play a significant role in determining the growth of bio-aerosols in an indoor environment (Onmek et al., 2020). These authors reported further that poor ventilation, crowded conditions, and an increase in the number of air conditions inside building nowadays can facilitate the spreading and the survival rates of airborne particles and also can increase the chance of people at risk of airborne infections. Amongst dust particles that are available in a typical indoor environment, fungi that reproduce through the formation of spores, some gram-positive bacteria, and some viruses have got the capability of surviving for a lengthy time in the air (Hassan et al., 2017). According to McCormick et al. (2010), although Aspergillus fumigatus does not have virulence traits and can resist environmental stresses, it is a key airborne fungus that can cause mass infection. These authors reported further that the fungus has the capability of triggering numerous human diseases if its conidia are huffed into the lungs.

Serna-Saldivar (2012) did define grain as a small, dry seed, hard that is or not attached to hull or fruit layer, garnered for the consumption of humans and animals. This author reported further that a grain crop is a grain-producing plant that has two key types being commercial grain crops which are cereals and legumes. The availability of a low water activity has practically made microbial contamination of grains flour an issue that is not noticeable as such (Dacarro et al., 2005). These authors further reiterated that flours generated from grains generally have a water activity $(0.87)$ level or lower depending on their moisture and temperature. Inhalation of bio-aerosols by workers in agricultural fields and those working with grains had led to many diseases like toxic syndrome, allergic alveolitis, and asthma (Dutkiewicz et al., 2000). Generation of dusty particles in grains' grinding mills is inevitable. These dusty particles encourage the unhindered growth of airborne microorganisms provided that there are favorable environmental conditions (Dacarro et al., 2005). It has been established by Weidenborner et al. (2000) that molds start growing in flours when the water content goes above a range of $13-15 \%$.

In a typical indoor environment, air that is breathed in by people is profusely inhabited with microorganisms known as bioaerosols ranging from bacteria, fungi, and molds Yassin and Almiuqatea (2010). Bioaerosols are constantly extant in our environment and the majority of the time, it may not be worrisome most especially if its quantity at source poses no problems and air quantities are kept within judicious bounds. Nevertheless, when some bioaerosols are inhaled into the lungs, it can lead to the development of airborne diseases like respiratory infections, pneumonia, asthma, and rhinitis (U.S National Institution of Health, 2014). Prevention and reduction of microbial contaminants in flours are viable alternatives adopted to enhance the acceptance of the final products coupled with aiding significant production costs in the milling process (Dacarro et al., 2005). According to Yassin and Almiuqatea (2010), a typical indoor environment enhances more favorable and optimum conditions for the existence of fungal aerosols. It is against this background that this study was conducted to assess the mycological indoor air quality of the grains' grinding mills in the Dutse ultra-modern market. The study was staged based on the null hypothesis that stated that there is no variation between the indoor fungal loads obtainable in the shops housing the grains' grinding mills.

\section{METHODS \\ Description of Study Area}

This study was conducted in the ultra-modern market situated in Dutse Urban. According to Peel et al. (2007), Dutse is the capital of Jigawa State, 
Nigeria. The authors reported further that geographically, it lies on latitude of $11^{\circ} 42^{\prime} 8.46^{\prime \prime} \mathrm{N}$ and longitude of $9^{\circ} 20^{\prime} 2.46^{\prime \prime} \mathrm{E}$. It is home to Federal University Dutse which was established in November 2011. Dutse ultra-modern market grains' grinding mills are located on the latitude of $11^{\circ} 41^{\prime} 31.7^{\prime \prime} \mathrm{N}$ and longitude of $9^{\circ} 20^{\prime} 47.3^{\prime \prime} \mathrm{E}$.

\section{Sampling Technique}

Out of the thirty (30) shops present in the grains' grinding mills, nine (9) shops were selected randomly for air sampling. Six (6) samples were collected from each selected shop in the morning, afternoon, and evening thereby leading to the collection of fifty-four (54) indoor air samples.

\section{Preparation of Culture Plates and Collection of} Air Samples

A sensitive weighing balance was used to measure sixty-five grams $(65 \mathrm{~g})$ of sabouraud dextrose agar (SDA) and $0.05 \mathrm{~g}$ chloramphenicol into a conical flask. It was subsequently dissolved with $100 \mathrm{~mL}$ of distilled water following the instructions of the manufacturer. Chloramphenicol was added to inhibit the growth of broad-spectrum bacteria on the agar plates during incubation ( $\mathrm{Sa}$ 'id and Salihu, 2018). The culture media was autoclaved and aseptically poured into fifty-four (54) sterilized petri dishes. The plates were labeled with sample number, time of collection, and operation status of the grinding mills.

The petri dishes were transported to the grains' grinding mills in sealed bags as done by Adeleye et al. (2018). Indoor air sampling was done using the settle plate method (Fekadu \& Getachewu, 2015). This was done by placing the prepared agar plates at a point that was very close to where each operator of the milling machines was standing in each shop, specifically at about one (1) meter above the ground representing human breathing zone (Adeleye et al., 2018). All the plates were exposed for twenty (20) minutes as prescribed by Sa'id and Salihu (2018). After this exposure, the agar plates were covered and immediately taken to the laboratory in sealed plastic bags. The agar plates were subsequently incubated for 5 days at $25{ }^{\circ} \mathrm{C}$ (Sa'id and Salihu, 2018).

\section{Enumeration and Identification of Fungal Isolates}

The enumeration of the fungal colonies was done with an electric colony counter leading to the generation of fungal Colony Forming Units (CFU).
Afterwards, the Colony Forming Units per cubic meter $\left(\mathrm{CFU} / \mathrm{m}^{3}\right)$ of the fungal isolates in the plates were determined using the equation outlined by Gutarowska (2010); Borrego et al. (2010); Enitan et al. (2017);

$\mathrm{N}=5 \mathrm{a} \times 10^{4}(\mathrm{bt})^{-1}$

Where:

$$
\begin{aligned}
& \mathrm{N}=\text { microbial } \mathrm{CFU} / \mathrm{m}^{3} \text { of indoor air } \\
& \mathrm{a}=\text { number of colonies per petri dish } \\
& \mathrm{b}=\text { dish surface area }\left(\mathrm{cm}^{2}\right) \\
& \mathrm{t}=\text { exposure time of the petri dish (in minutes). } \\
& \text { Fungal colonies that had similar colonial }
\end{aligned}
$$
attributes were subsequently sub-cultured into sterile SDA plates and further incubated for 5 days at $25^{\circ} \mathrm{C}$. Fungal isolates were identified on the basis of macroscopic and microscopic examinations as outlined by Hayleeyesus and Manaye (2014); Enitan et al. (2017). This was done by adding a drop of distilled water at the center of a clean grease-free glass slide labeled A and B. Loopful of a fungal colony was collected from the fungal growth observed on the culture plates, mixed and a thin smear was made into a separate slide. The smears were allowed to air dry and heat-fixed by passing it three (3) times over a spirit lamp. The smears were placed on a staining rack. The smears were covered with a Lacto-phenol cotton blue stain for sixty (60) seconds. The two smears were rinsed with running water. The smears were allowed to air dry, the back of the glass slide was wiped with a piece of cotton wool. The glass slide was mounted on the microscope stage and observed using $\times 10$ and $x 40$ objective lens. The morphology and cell arrangement were observed, snapped with an android phone, and recorded accordingly. Fungal isolates were identified with the aid of an Atlas of Mycology as described by Enitan et al. (2017).

\section{Data Analyses}

Descriptive statistics in form of tables were used to summarize results generated from the fungal Colony Forming Unit, colonial attributes, microscopic characteristics, and fungi identified. Results obtained on the fungal loads across all the shops and varying sample collection periods were subjected to analysis by Proc. GLM of GenStat version 17 and the means were separated using Duncan Multiple Range Test (DMRT). 
RESULTS AND DISCUSSION

Fungal Loads Obtained in the Indoor Air of the Sampled Grinding Mills

A total of fifty-four (54) samples were collected during this study. The shop, sample

Table 1. Fungal Load Obtained in Samples from Shop A

\begin{tabular}{|c|c|c|c|c|c|}
\hline Sample & Label & OS & Time & Period & CFU $/ \mathrm{m}^{3}$ \\
\hline 1 & SDA $_{36}$ & Active & $8 \mathrm{am}-9 \mathrm{am}$ & Morning & 2544 \\
\hline 2 & $\mathrm{SDA}_{35}$ & Active & $9 \mathrm{am}-10 \mathrm{am}$ & Morning & 4035 \\
\hline 3 & $\mathrm{SDA}_{11}$ & Active & $1 \mathrm{pm}-2 \mathrm{pm}$ & Afternoon & 3860 \\
\hline 4 & $\mathrm{SDA}_{10}$ & Not Active & $2 \mathrm{pm}-3 \mathrm{pm}$ & Afternoon & 3596 \\
\hline 5 & $\mathrm{SDA}_{17}$ & Not Active & $4 \mathrm{pm}-5 \mathrm{pm}$ & Evening & 2018 \\
\hline 6 & $\mathrm{SDA}_{46}$ & Active & $5 \mathrm{pm}-6 \mathrm{pm}$ & Evening & 3421 \\
\hline
\end{tabular}

Note: $\mathrm{OS}=$ Operation status; $\mathrm{CFU}=$ Colony Forming Unit

Specifically, in shop A, it can be observed that when the grinding mils were in operation, the obtained fungal loads ranged between 2544 and

$4035 \mathrm{CFU} / \mathrm{m}^{3}$ while it ranged from 2018 and 3596 $\mathrm{CFU} / \mathrm{m}^{3}$ when the grinding mills were not in operation (Table 1).

Table 2. Fungal Load Obtained in Samples from Shop B

\begin{tabular}{|c|c|c|c|c|c|}
\hline Sample & Label & OS & Time & Period & CFU $/ \mathrm{m}^{3}$ \\
\hline 1 & $\mathrm{SDA}_{6}$ & Active & $8 \mathrm{am}-9 \mathrm{am}$ & Morning & 4298 \\
\hline 2 & $\mathrm{SDA}_{45}$ & Not Active & $9 \mathrm{am}-10 \mathrm{am}$ & Morning & 3465 \\
\hline 3 & $\mathrm{SDA}_{31}$ & Active & $1 \mathrm{pm}-2 \mathrm{pm}$ & Afternoon & 5614 \\
\hline 4 & $\mathrm{SDA}_{41}$ & Not Active & $2 \mathrm{pm}-3 \mathrm{pm}$ & Afternoon & 3421 \\
\hline 5 & $\mathrm{SDA}_{18}$ & Active & $4 \mathrm{pm}-5 \mathrm{pm}$ & Evening & 4912 \\
\hline 6 & $\mathrm{SDA}_{47}$ & Not Active & $5 \mathrm{pm}-6 \mathrm{pm}$ & Evening & 4035 \\
\hline
\end{tabular}

Note: $\mathrm{OS}=$ Operation status; $\mathrm{CFU}=$ Colony Forming Unit

In shop B, the fungal loads recorded when the grinding mills were in operation ranged between 4298 and $5614 \mathrm{CFU} / \mathrm{m}^{3}$ while it ranged between

3421 and $4035 \mathrm{CFU} / \mathrm{m}^{3}$ when the mills were not in operation (Table 2).

Table 3. Fungal Load Obtained in Samples from Shop C

\begin{tabular}{|c|c|c|c|c|c|}
\hline Sample & Label & OS & Time & Period & $\mathrm{CFU} / \mathrm{m}^{3}$ \\
\hline 1 & $\mathrm{SDA}_{27}$ & Active & $8 \mathrm{am}-9 \mathrm{am}$ & Morning & 6228 \\
\hline 2 & $\mathrm{SDA}_{30}$ & Active & $9 \mathrm{am}-10 \mathrm{am}$ & Morning & 6623 \\
\hline 3 & $\mathrm{SDA}_{32}$ & Not Active & $1 \mathrm{pm}-2 \mathrm{pm}$ & Afternoon & 4649 \\
\hline 4 & $\mathrm{SDA}_{09}$ & Not Active & $2 \mathrm{pm}-3 \mathrm{pm}$ & Afternoon & 3333 \\
\hline 5 & $\mathrm{SDA}_{08}$ & Not Active & $4 \mathrm{pm}-5 \mathrm{pm}$ & Evening & 2807 \\
\hline 6 & $\mathrm{SDA}_{48}$ & Active & $5 \mathrm{pm}-6 \mathrm{pm}$ & Evening & 4298 \\
\hline
\end{tabular}

Note: $\mathrm{OS}=$ Operation status; $\mathrm{CFU}=$ Colony Forming Unit

In shop $\mathrm{C}$, it can be observed that while the grinding mills were not milling grains, the fungal loads ranged between 2807 and $4649 \mathrm{CFU} / \mathrm{m}^{3}$ while it ranged between 4298 and $6228 \mathrm{CFU} / \mathrm{m}^{3}$ when it was in operation (Table 3). 
Table 4. Fungal Load Obtained in Samples from Shop D

\begin{tabular}{|c|c|c|c|c|c|}
\hline Sample & Label & OS & Time & Period & CFU $/ \mathrm{m}^{3}$ \\
\hline 1 & $\mathrm{SDA}_{20}$ & Active & $8 \mathrm{am}-9 \mathrm{am}$ & Morning & 5746 \\
\hline 2 & $\mathrm{SDA}_{25}$ & Active & $9 \mathrm{am}-10 \mathrm{am}$ & Morning & 3246 \\
\hline 3 & $\mathrm{SDA}_{23}$ & Not Active & $1 \mathrm{pm}-2 \mathrm{pm}$ & Afternoon & 3728 \\
\hline 4 & $\mathrm{SDA}_{03}$ & Not Active & $2 \mathrm{pm}-3 \mathrm{pm}$ & Afternoon & 3553 \\
\hline 5 & $\mathrm{SDA}_{13}$ & Active & $4 \mathrm{pm}-5 \mathrm{pm}$ & Evening & 4693 \\
\hline 6 & $\mathrm{SDA}_{49}$ & Active & $5 \mathrm{pm}-6 \mathrm{pm}$ & Evening & 4912 \\
\hline
\end{tabular}

Note: $\mathrm{OS}=$ Operation status; $\mathrm{CFU}=$ Colony Forming Unit

The highest fungal load $\left(5746 \mathrm{CFU} / \mathrm{m}^{3}\right)$ recorded in shop D when the grinding mills were in operation was recorded in the morning between 8 and 9 am while the lowest fungal load (3553

Table 5. Fungal Load Obtained in Samples from Shop E

\begin{tabular}{|c|c|c|c|c|c|}
\hline Sample & Label & OS & Time & Period & CFU $/ \mathrm{m}^{3}$ \\
\hline 1 & $\mathrm{SDA}_{39}$ & Not Active & $8 \mathrm{am}-9 \mathrm{am}$ & Morning & 1930 \\
\hline 2 & $\mathrm{SDA}_{42}$ & Not Active & $9 \mathrm{am}-10 \mathrm{am}$ & Morning & 3421 \\
\hline 3 & $\mathrm{SDA}_{24}$ & Not Active & $1 \mathrm{pm}-2 \mathrm{pm}$ & Afternoon & 3246 \\
\hline 4 & $\mathrm{SDA}_{07}$ & Not Active & $2 \mathrm{pm}-3 \mathrm{pm}$ & Afternoon & 2588 \\
\hline 5 & $\mathrm{SDA}_{28}$ & Active & $4 \mathrm{pm}-5 \mathrm{pm}$ & Evening & 4474 \\
\hline 6 & $\mathrm{SDA}_{50}$ & Active & $5 \mathrm{pm}-6 \mathrm{pm}$ & Evening & 4649 \\
\hline
\end{tabular}

Note: $\mathrm{OS}=$ Operation status; $\mathrm{CFU}=$ Colony Forming Unit

In shop E, the fungal loads recorded when the grinding mills were in operation ranged between 4474 and $4649 \mathrm{CFU} / \mathrm{m}^{3}$ while it ranged between

1930 and $3421 \mathrm{CFU} / \mathrm{m}^{3}$ when the grinding mills were not in operation (Table 5).

Table 6. Fungal Load Obtained in Samples from Shop F

\begin{tabular}{|c|c|c|c|c|c|}
\hline Sample & Label & OS & Time & Period & CFU $/ \mathrm{m}^{3}$ \\
\hline 1 & $\mathrm{SDA}_{43}$ & Not Active & $8 \mathrm{am}-9 \mathrm{am}$ & Morning & 3860 \\
\hline 2 & $\mathrm{SDA}_{26}$ & Active & $9 \mathrm{am}-10 \mathrm{am}$ & Morning & 5877 \\
\hline 3 & $\mathrm{SDA}_{22}$ & Active & $1 \mathrm{pm}-2 \mathrm{pm}$ & Afternoon & 4649 \\
\hline 4 & $\mathrm{SDA}_{04}$ & Not Active & $2 \mathrm{pm}-3 \mathrm{pm}$ & Afternoon & 4430 \\
\hline 5 & $\mathrm{SDA}_{01}$ & Not Active & $4 \mathrm{pm}-5 \mathrm{pm}$ & Evening & 2456 \\
\hline 6 & $\mathrm{SDA}_{51}$ & Active & $5 \mathrm{pm}-6 \mathrm{pm}$ & Evening & 4649 \\
\hline
\end{tabular}

Note: $\mathrm{OS}=$ Operation status; $\mathrm{CFU}=$ Colony Forming Unit

In shop $\mathrm{F}$, when the grinding mills were in operation, the highest fungal load recorded was $5877 \mathrm{CFU} / \mathrm{m}^{3}$ while the lowest fungal load deduced
$\mathrm{CFU} / \mathrm{m}^{3}$ ) was recorded when the grinding mills were not in operation was recorded in the afternoon (Table 4). were not in operation (Table 5).

$$
\text { F }
$$


Table 7. Fungal Load Obtained in Samples from Shop G

\begin{tabular}{|c|c|c|c|c|c|}
\hline Sample & Label & OS & Time & Period & CFU $/ \mathrm{m}^{3}$ \\
\hline 1 & $\mathrm{SDA}_{37}$ & Not Active & $8 \mathrm{am}-9 \mathrm{am}$ & Morning & 1667 \\
\hline 2 & $\mathrm{SDA}_{21}$ & Active & $9 \mathrm{am}-10 \mathrm{am}$ & Morning & 4737 \\
\hline 3 & $\mathrm{SDA}_{16}$ & Active & $1 \mathrm{pm}-2 \mathrm{pm}$ & Afternoon & 4035 \\
\hline 4 & $\mathrm{SDA}_{40}$ & Not Active & $2 \mathrm{pm}-3 \mathrm{pm}$ & Afternoon & 2281 \\
\hline 5 & $\mathrm{SDA}_{38}$ & Not Active & $4 \mathrm{pm}-5 \mathrm{pm}$ & Evening & 2149 \\
\hline 6 & $\mathrm{SDA}_{52}$ & Not Active & $5 \mathrm{pm}-6 \mathrm{pm}$ & Evening & 2456 \\
\hline
\end{tabular}

Note: $\mathrm{OS}=$ Operation status; $\mathrm{CFU}=$ Colony Forming Unit

During indoor air sampling in shop $G$, the fungal loads ranged between 4035 and 4737 $\mathrm{CFU} / \mathrm{m}^{3}$ when the grinding mills were in operation while it ranged between 1667 and $2456 \mathrm{CFU} / \mathrm{m}^{3}$ when the grinding mills were not in operation (Table 7).

Table 8. Fungal Load Obtained in Samples from Shop H

\begin{tabular}{|c|c|c|c|c|c|}
\hline Sample & Label & OS & Time & Period & CFU $/ \mathrm{m}^{3}$ \\
\hline 1 & $\mathrm{SDA}_{34}$ & Active & $8 \mathrm{am}-9 \mathrm{am}$ & Morning & 3947 \\
\hline 2 & $\mathrm{SDA}_{33}$ & Not Active & $9 \mathrm{am}-10 \mathrm{am}$ & Morning & 3553 \\
\hline 3 & $\mathrm{SDA}_{12}$ & Active & $1 \mathrm{pm}-2 \mathrm{pm}$ & Afternoon & 4474 \\
\hline 4 & $\mathrm{SDA}_{14}$ & Not Active & $2 \mathrm{pm}-3 \mathrm{pm}$ & Afternoon & 3026 \\
\hline 5 & $\mathrm{SDA}_{02}$ & Not Active & $4 \mathrm{pm}-5 \mathrm{pm}$ & Evening & 3158 \\
\hline 6 & $\mathrm{SDA}_{53}$ & Active & $5 \mathrm{pm}-6 \mathrm{pm}$ & Evening & 4035 \\
\hline
\end{tabular}

Note: $\mathrm{OS}=$ Operation status; $\mathrm{CFU}=$ Colony Forming Unit

When there was no grinding operation going on in shop $\mathrm{H}$, fungal loads detected ranged between 3026 and $3553 \mathrm{CFU} / \mathrm{m}^{3}$ whereas the fungal loads

recorded when there was grinding activity going on ranged between 3947 and $4474 \mathrm{CFU} / \mathrm{m}^{3}$ (Table 8).

Table 9. Fungal Load Obtained in Samples from Shop I

\begin{tabular}{|c|c|c|c|c|c|}
\hline Sample & Label & OS & Time & Period & CFU $/ \mathrm{m}^{3}$ \\
\hline 1 & $\mathrm{SDA}_{44}$ & Active & $8 \mathrm{am}-9 \mathrm{am}$ & Morning & 4211 \\
\hline 2 & $\mathrm{SDA}_{05}$ & Active & $9 \mathrm{am}-10 \mathrm{am}$ & Morning & 4123 \\
\hline 3 & $\mathrm{SDA}_{15}$ & Not Active & $1 \mathrm{pm}-2 \mathrm{pm}$ & Afternoon & 3465 \\
\hline 4 & $\mathrm{SDA}_{29}$ & Active & $2 \mathrm{pm}-3 \mathrm{pm}$ & Afternoon & 4781 \\
\hline 5 & $\mathrm{SDA}_{19}$ & Active & $4 \mathrm{pm}-5 \mathrm{pm}$ & Evening & 5351 \\
\hline 6 & $\mathrm{SDA}_{54}$ & Active & $5 \mathrm{pm}-6 \mathrm{pm}$ & Evening & 4474 \\
\hline
\end{tabular}

Note: $\mathrm{OS}=$ Operation status; $\mathrm{CFU}=$ Colony Forming Unit

However, in shop I, the highest fungal load obtained during grinding operation in the afternoon was $4781 \mathrm{CFU} / \mathrm{m}^{3}$ while the lowest fungal load recorded in the absence of grinding operation in the afternoon was $3465 \mathrm{CFU} / \mathrm{m}^{3}$ (Table 9). It can be observed that the indoor air sampling of the grinding mills was done in the morning (8-10 am), afternoon (1-3 pm), and evening (4-6 pm). When the grinding mill was in operation in the morning, the highest $\left(4035 \mathrm{CFU} / \mathrm{m}^{3}\right)$ fungal load recorded in shop A was obtained on $\mathrm{SDA}_{25}$ (Table 1). However, when the grinding mill was not in operation, the lowest $\left(2018 \mathrm{CFU} / \mathrm{m}^{3}\right)$ fungal load was obtained on $\mathrm{SDA}_{17}$ in the evening (Table 1). When the grinding mill was in operation in the afternoon, the highest $\left(5614 \mathrm{CFU} / \mathrm{m}^{3}\right)$ fungal load recorded in shop B was obtained on $\mathrm{SDA}_{31}$ (Table 2). Conversely, when the grinding mill was not in operation, the lowest $\left(3421 \mathrm{CFU} / \mathrm{m}^{3}\right)$ fungal load was obtained on $\mathrm{SDA}_{41}$ in the afternoon (Table 2).

Generally, it can be observed across all the shops that irrespective of the sampling time, fungal loads obtained when grinding mills were in operation were always more than the fungal loads 
obtained when the grinding mills were not in operation (Tables 1-9). During air sampling, it was observed that workers in the grinding mils had no protective device on. This implies that more of these fungal aerosols were more likely to be inhaled during this space of time. Table 10 depicts the results of the mean fungal load obtained during air sampling in the shops.

Table 10. Mean Fungal Load Obtained during Air Sampling in the Shops

\begin{tabular}{|c|c|c|}
\hline \multicolumn{3}{|c|}{ Mean fungal load $\left(\mathrm{CFU} / \mathrm{m}^{3}\right)$} \\
\hline Morning & Afternoon & Evening \\
\hline 4084 & 3818 & 3867 \\
\hline
\end{tabular}

Results obtained indicate that depending on the sampling period and operation status of the grinding mills, all the sampling points examined were heavily contaminated with total mean fungal load in the morning (4085 $\left.\mathrm{CFU} / \mathrm{m}^{3}\right)$, evening (3866 $\left.\mathrm{CFU} / \mathrm{m}^{3}\right)$, and afternoon $\left(3818 \mathrm{CFU} / \mathrm{m}^{3}\right)$ (Table 10$)$.

Colonial and Microscopic Characteristics of the Isolated Fungi

The colonial attributes and microscopic characteristics of the isolated fungi are depicted in (Table 11).

$\mathrm{CFU}=$ Colony Forming Unit

Table 11. Colonial and Microscopic Characteristics of the Identified Fungi

\begin{tabular}{|c|c|c|}
\hline $\begin{array}{c}\text { Colonial Attributes } \\
\text { Fairly distinct, blackish flat and coarse } \\
\text { colonies }\end{array}$ & $\begin{array}{c}\text { Meptate hyphae with a large } \\
\text { sporangiosphore }\end{array}$ & Fungi Identified \\
\hline $\begin{array}{c}\text { Yellow to green colonies which later } \\
\text { turned brown }\end{array}$ & $\begin{array}{c}\text { Septate hyphae with filamentous } \\
\text { structure }\end{array}$ & $\begin{array}{c}\text { Aspergillus } \\
\text { flavus }\end{array}$ \\
\hline $\begin{array}{c}\text { Candy like colonies, whitish, turned brown } \\
\text { at the center }\end{array}$ & $\begin{array}{c}\text { Septate hyphae with macro conidia } \\
\text { growing on sporangiosphore }\end{array}$ & Fusarium spp. \\
\hline $\begin{array}{c}\text { Fast growing colonies, white to grey cotton } \\
\text { candy, and darkening }\end{array}$ & $\begin{array}{c}\text { Non Septate hyphae with } \\
\text { sporangiosphore }\end{array}$ & Mucorplambeaus \\
\hline $\begin{array}{c}\text { Colonies having green fluffy mycelia with } \\
\text { white sporangiosphore }\end{array}$ & $\begin{array}{c}\text { Septate hyphae with filamentous } \\
\text { structure }\end{array}$ & Penicillium spp. \\
\hline
\end{tabular}

It can be seen that four (4) airborne fungi ranging from Aspergillus niger and Penicillium spp. were isolated and identified in the grinding mills (Table 11). The detection of these fungi in this study corroborates the findings of Amengialue et al. (2017) who reported the isolation of Penicillium spp., Aspergillus spp., Aspergillus niger, and Table 12. Occurrence Frequency of the Isolated Fungi

\begin{tabular}{|c|c|c|}
\hline Fungi Isolates & Number of Isolates & Frequency (\%) \\
\hline Aspergillus flavus & 9 & 16.67 \\
\hline Mucorplambeus & 12 & 22.22 \\
\hline Fusarium spp. & 12 & 22.22 \\
\hline Aspergillus niger & 11 & 20.37 \\
\hline Penicilliumspp. & 10 & 18.52 \\
\hline Total & 54 & 100 \\
\hline
\end{tabular}

The most frequent fungal isolates were Mucorplambeus and Fusarium spp. with a percentage frequency of $22.22 \%$ and $22.22 \%$ respectively while the least occurred fungal isolate
Mucorplambeus at the University of Benin. The results obtained in this study are also in agreement with that of Sekulska et al. (2007) who detected some strains of Fusarium, Penicillium, and Rhizopus in University rooms. The occurrence frequency of the fungi isolated from the sampled air is presented in Table 12. was Aspergillus flavus with a percentage frequency of $16.67 \%$ (Table 12). The results of the present study agree with the reports of Würtz et al. (1999); Meklin (2002) who isolated molds belonging to the 
genera Penicillium and Aspergillus from the indoor air of some Norwich schools and Danish schools respectively. It also agrees with the report of Kumari et al. (2015); Canha et al. (2015) on the detection of Penicllium spp., Yeasts, and Aspegillus spp. In their study area. The findings in this current study equally coincide with the report of Dacarro et al. (2005) on the detection of Aspergillus spp., Penicillium spp. in an Italian grind mill. These authors implicated mycetes of Aspergillus genus as the main threat causing pathologies connected with dust particles emanating from organic sources. Naga et al. (2015) equally reported the occurrence of Aspergillus spp., Penicillium spp., and Rhizopus spp. as the dominant fungal isolates in an indoor environment.

Many authors (Bünger et al., 2000; Douwes et al., 2003; Viegas et al., 2015) have reported aspergillosis in immunosuppressed individuals exposed to bio-aerosols in their workplace. Mucorplambeus, Penicillium spp., Fusarium spp., Aspergillus flavus, and Aspergillus niger isolated in this current study have been implicated as opportunistic pathogens for humans and often associated with clinical manifestations of allergy, rhinitis, asthma, cancer, and conjunctivitis. Also, these fungi are considered potential candidates involved in the establishment of sick building syndromes (Sa'id and Salihu, 2018). Sundaram et al. (2002) has attributed pneumoconiosis which is known as flour mill lung to inhalation of dusts generated from grains.

Table 13. Variations in the Mean Fungal Loads during Sample Collection

\begin{tabular}{|c|c|c|c|}
\hline & \multicolumn{3}{|c|}{ Fungal Load $\left(\mathrm{CFU} / \mathrm{m}^{3}\right)$} \\
\hline Shop & Morning & Afternoon & Evening \\
\hline A & $3290^{\mathrm{bc}}$ & $3728^{\mathrm{bc}}$ & $2720^{\mathrm{bc}}$ \\
\hline B & $3882^{\mathrm{bc}}$ & $4518^{\mathrm{acc}}$ & $4474^{\mathrm{acc}}$ \\
\hline C & $6426^{\mathrm{a}}$ & $3991^{\mathrm{bc}}$ & $3868^{\mathrm{bc}}$ \\
\hline D & $4496^{\mathrm{abc}}$ & $3640^{\mathrm{bc}}$ & $4802^{\mathrm{ab}}$ \\
\hline E & $2676^{\mathrm{bc}}$ & $2917^{\mathrm{bc}}$ & $4562^{\mathrm{acc}}$ \\
\hline F & $4869^{\mathrm{ab}}$ & $4540^{\mathrm{abc}}$ & $3553^{\mathrm{bc}}$ \\
\hline G & $3202^{\mathrm{bc}}$ & $3158^{\mathrm{bc}}$ & $2302^{\mathrm{c}}$ \\
\hline H & $3750^{\mathrm{bc}}$ & $3750^{\mathrm{bc}}$ & $3597^{\mathrm{bc}}$ \\
\hline I & $4167^{\mathrm{abc}}$ & $4123^{\mathrm{acc}}$ & $4913^{\mathrm{ab}}$ \\
\hline
\end{tabular}

Note: Means with the same letters in each column are not significantly different using Duncan multiple range test (DMRT) $(\mathrm{p}>0.05)$.
In reference to the Commission of the European Communities (CEC), American Conference of Governmental Industrial Hygienists (ACGIH), and Occupational Safety and Health Administration (OSHAA) standards and groupings (Kim et al., 2018), the indoor air of grains grinding mills of ultra-modern market Dutse, generally showed a high level of fungal contamination levels as the identified fungi recorded in the grinding mills fell in the range of the recommended fungal counts $\left(>10^{3} \mathrm{CFU} / \mathrm{m}^{3}\right)$ as against the earlier findings of Adeleye et al. (2018). Even though Bragoszewska and Biedron (2018) did report difficulty in the characterization of work-related risks associated with airborne pathogens, the risks attributable to the isolated and identified fungi in this study should be a source of concern as workers and people that come in contact with the bioaerosols detected in the grinding mills are potentially exposed to such and may be susceptible to its associated ill health effects after all.

Results generated from air sampling indicated that the mean fungal loads obtained in the morning from shops A $\left(3290 \mathrm{CFU} / \mathrm{m}^{3}\right), \mathrm{B}\left(3882 \mathrm{CFU} / \mathrm{m}^{3}\right)$, D $\left(4496 \mathrm{CFU} / \mathrm{m}^{3}\right), \quad$ E $\left(2676 \mathrm{CFU} / \mathrm{m}^{3}\right), \quad$ F $(4869$ $\left.\mathrm{CFU} / \mathrm{m}^{3}\right), \mathrm{G}\left(3202 \mathrm{CFU} / \mathrm{m}^{3}\right), \mathrm{H}\left(3750 \mathrm{CFU} / \mathrm{m}^{3}\right)$ and I $\left(4167 \mathrm{CFU} / \mathrm{m}^{3}\right)$ were not significantly $(\mathrm{p}>0.05)$ different from each other. However, the mean fungal load obtained in the morning from shop $\mathrm{C}$ $\left(6426 \mathrm{CFU} / \mathrm{m}^{3}\right)$ was significantly $(\mathrm{p}<0.05)$ different from the fungal loads obtained in other shops (Table 13). 
In the afternoon, the mean fungal loads recorded in all the shops were significantly $(p>$ 0.05 ) different from each other. The same trend was witnessed in the evening as the mean fungal loads recorded across all the shops were not significantly $(\mathrm{p}>0.05)$ different from each other (Table 13).

\section{CONCLUSION}

In this study, Mucorplambeaus, Aspergillus flavus, Aspergillus niger, Fussarium spp., and Penicillium spp. Were isolated across all the air sampling points using the simple staining technique. The fungi isolated in this study have been established as causative agents of several fungal infections which can be potentially and readily picked up by the workers and customers that come in contact with the indoor air of the grinding mills. Specifically, allergies, rhinitis, asthma, cancer, and conjunctivitis are the reported diseases synonymous with the fungi isolated from the grains' grinding mills. The results obtained in this study have clearly indicated that depending on the time of the day and operation status of the various shops housing the grinding mills, the indoor environment allows fungal aerosols to build up which could serve as potential reservoirs of fungal infections. The concentrations of aero flora above the permissive standard recorded in this study, underscore the importance of this microenvironment for high exposure of humans to bio-aerosols.

Based on the findings recorded in this study, it is therefore recommended that a proper ventilation system should be provided to allow the movement of air in and out of the grinding mills. Proper control measures have to be taken to prevent the environmental factors which facilitate the growth and proliferation of pathogenic fungi in the workplace. Disinfection of floors should be performed routinely and dust from the grinding process should be prevented to the barest minimum. Workers and customers that visit the grinding mills should be mandated to wear face masks for their safety. Finally, as this study focused on the isolation of fungal airborne pathogens, future studies may be required to isolate bacterial pathogens which could be a good source of air-borne pathogens in the grinding mills.

\section{REFERENCES}

1. Abed, E.Y. (2014). Assessment of Indoor Microbial Quality of Science Laboratories at Three Universities in Gaza City. A Thesis Submitted in Partial Fulfilment of the Requirement for the Degree of Master of Science in Environmental Sciences, The Islamic University - Gaza - Palestine. Available at

http://library.iugaza.edu.ps/thesis/114758.pdf.

2. Adeleye, A. O., Amoo, A. O., Omokhudu, G. I., Hassan, A., Olatomiwa, O. J. and Zakariyya, M. K. (2018). Indoor Air Quality Assessment of Federal University Dutse Library North West, Nigeria. J. Appl. Sci. Environ. Manage., 22 (10): 1621-1624.

3. Amengialue, O. O., Okwu, G. I., Oladimeji, O. R. and Iwuchukwu, A. A. (2017). Microbiological Quality Assessment of Indoor Air of a Private University in Benin City, Nigeria. IOSR Journal of Pharmacy and Biological Sciences (IOSRJPBS), 12 (3): 19-25.

4. Borrego, S., Guiamet, P., Gómez and Saravia, P. (2010). The Quality of Air at Archives and the Biodeterioration of Photographs. International Biodeterioration and Biodegradation, 64 (2): 139-145.

5. Brągoszewska, E. and Biedroń, I. (2018) Indoor air quality and potential health risk impacts of exposure to antibiotic resistant bacteria in an office rooms in Southern Poland. International Journal of Environmental Research in Public Health, 15. Retrieved from https://doi.org/10.3390/ijerph15112604.A ccessed on 23rd August, 2021.

6. Bünger, J., Antlauf-Lammers, M., Schulz, T.G., Westphal, G.A., Müller, M.M., Ruhnau, P. and Hallier, E. (2000). Health Complaints and Immunological Markers of Exposure to Bioaerosols among Biowaste Collectors and Compost Workers. Occup. Environ. Med., 57: 458-464.

7. Canha, N., Almeida, S. M., Freitas, M. C. and Wolterbeek, H. T. (2015). Assessment of Bioaerosols in Urban and Rural Primary Schools Using Passive and Active Sampling Methodologies. Archives of Environmental Protection, 41 (4): 11-22. 
8. Dacarro, C., Grisoli, P., Del, F. G., Villani, S., Grignani, E. and Cottica, D. (2005). Micro-organisms and Dust Exposure in an Italian Grain Mill. Journal of Applied Microbiology, 98 (1): 163-171.

9. Douwes, J., Thorne, P., Pearce, N. and Heederik, D. (2003). Bioaerosol health effects and exposure assessment: progress and prospects. Annals of Occupational Hygiene, 47 (3): 187-200.

10. Dutkiewicz, J., Krysin'ska-Traczyk, E., Sko'rska, C., Sitkowska, J., Prazmo, Z. and Urbanowicz, B. (2000). Exposure of Agricultural Workers to Airborne Microoorganisms and Endotoxin during Handling of Various Vegetable Products. Aerobiologia, 16: 193-198.

11. Enitan, S. S., Ihongbe, J. C., Ochei, J. O., Effedua, H. I., Adeyemi, O. and Phillips, T. (2017). Microbiological Assessment of Indoor Air Quality of Some Selected Private Primary Schools in Ilishan-Remo, Ogun state, Nigeria. International Journal of Medical and Health Research, 3(6): 08-19.

12. Fekadu, S. and Getachewu, B. (2015). Microbiological Assessment of Indoor Air of Teaching Hospital Wards: A Case of Jimma University Specialized Hospital. Ethiopian Journal of Health Science, 25 (2): 117-122.

13. Hassan, M. M., Fiddausi, U., Madinat, R., Muhammad, M., Sulaiman, M.A. and Munzali, S. Z. (2017). Isolation and Identification of Airborne Bacteria from Federal University Dutse Lecture Rooms. International Journal of Scientific and Technology Research, 6 (9): 1619.

14. Hayleeyesus, S. F. and Manaye, A. M. (2014). Microbiological Quality of Indoor Air in University Libraries. Asian Pacific Journal of Tropical Biomedicine, 4 (1): 312-317.

15. Kim, K. H., Kabir, E. and Jahan, S. A. (2018). Airborne Bio-aerosols and their Impact on Human Health. Journal of Environmental Science, 67: 23-35.

16. Kumari, N. K., Shravanthi, C. M. and Reddy, T. B. (2015). Identification and Assessment of Airborne Bacteria in Selected School Environments in Visakhapatnam, India. Indian Journal of Scientific Research and Technology, 3 (6): 21-25.
17. Madukasi, E. I., Dai, X., He, C. and Zhou, J. (2010). Potentials of Phototrophic Bacteria in Treating Pharmaceutical Wastewater. International Journal of Environmental Science and Technology, 7 (1): 165-174.

18. McCormick, A., Loeffler, J. and Ebel. F. (2010). Aspergillus Fumigatus: Contours of an Opportunistic Human Pathogen. Cellular Microbiology, 12 (11): 1535-1543.

19. McMahon, S., Hope, J., Thrasher, J., Rea, W., Vinitsky, A. \& Gray, M. (2012). Common Toxins in Our Homes, Schools and Workplaces. Global Indoor Health Network, Inc. Henderson, NV 89077-7308.

20. Meklin, T. (2002). Microbial Exposure and Health in Schools: Effects of Moisture Damage and Renovation. Academic Dissertation, Department of Environmental Sciences, University of Kuopio, Kuopio, Finland. pp 181.

21. Naga, K., Mohan, M., Ramprasad, S. and Maruthi, Y. A. (2015). Microbiological Air Quality of Indoors in Primary and Secondary Schools of Visakhapatnam, India. International Journal of Current Microbiology and Applied Science, 3 (8): 880-887.

22. Nejadkoorki, F. (2015). Current Air Quality Issues: Biological Contamination of Air in Indoor Spaces. Available at https://www.intechopen.com/books/4572. Accessed on August 1st, 2021.

23. Onmek, N., Kongcharoen, J., Singtong, A., Penjumrus, A. and Junnoo, S. (2020). Environmental Factors and Ventilation Affect Concentrations of Microorganisms in Hospital Wards of Southern Thailand. Journal of Environmental and Public Health, 2020, 8 pages. Available at https://doi.org/10.1155/2020/7292198. Accessed on 28th July, 2021.

24. Sa'id, A. S. and Salihu, A. A. (2017). Microbiological Quality of Indoor Air in Some Selected Buildings at Modibbo Adamawa University of Technology, Yola. Umaru Musa Yar'adua University Journal of Microbiology, 3 (1): 1-5.

25. Sekulska, M., Piotraszewska-Pajak A., Szyszka A., Nowicki, M., and Filipiak, M. (2007). Microbiological Quality of Indoor Air in 
University Rooms. Polish Journal of Environmental Studies, 16 (4): 623-632.

26. Serna-Saldivar, S. O. (2012). Cereal Grains: Laboratory Reference and Procedures Manual. Food Preservation Technology. pp. 58.

27. Sundaram, P., Kamat, R. and Joshi, J.M. (2002) Flour mill lung: A pneumoconiosis of mixed aetiology. The Indian Journal of Chest Diseases and Allied Sciences, 44: 199-201.

28. U.S National Institution of Health (2014). Indoor air pollution. National Institute of Environmental Health Science. Retrieved from https://www.niehs.nih.gov. Accessed on 28th August, 2021.

29. Verde, S. C., Almeida, S. M., Matos, J., Guerreiro, D., Meneses, M., Faria, T. and Viegas, C. (2015). Microbiological Assessment of Indoor Air Quality at Different Hospital Sites.Research in Microbiology, 166 (7): $557-$ 563.

30. Weidenborner, M., Wieczorek, C., Appel, S. and Kunz, B. (2000). Whole wheat and white wheat flour - the mycobiota and potential mycotoxins. Food Microbiology, 17: 103-107.

31. Würtz, H., Kildeso, J., Meyer, H. W. and Nielsen, J. B. (1999). A Pilot Study on Airborne Microorganisms in Danish Classrooms. Proceedings of the 8th International Conference on Indoor Air Quality and Climate, Edinburgh, Scotland.

32. Yassin, M. and Almouqatea, S. (2010). Assessment of airborne bacteria and fungi in an indoor and outdoor environment. International Journal of Environmental Science and Technology, 7: 535-544. 